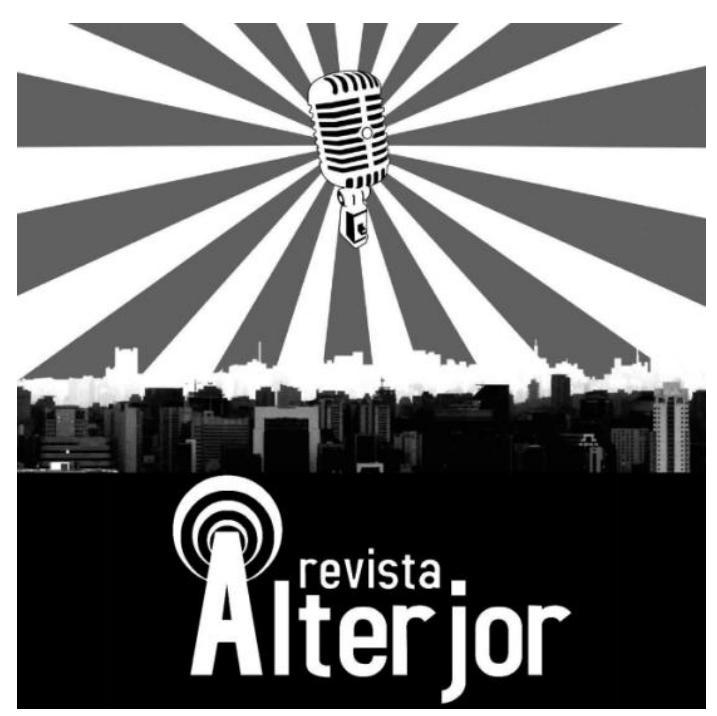

ENTREVISTA

\title{
AS MÚLTIPLAS EMISSORAS DE ROBSON CÉSAR: UM DEPOIMENTO SOBRE AS RÁDIOS LIVRES SOROCABANAS
}

\author{
Felipe Parra Alves de Oliveira ${ }^{1}$
}

\begin{abstract}
RESUMO: As rádios livres são meios de comunicação clandestinos que reverberam ideias livremente pelo espaço eletromagnético. Em específico, essas radiodifusoras criam discursos distantes dos interesses do monopólio das telecomunicações. Tais iniciativas experimentavam formas democráticas de gestão ao estimular que o sujeito sem experiência com a mídia opere uma emissora radiofônica. Em Sorocaba/SP , essa ação popular obteve destaque nacional e internacional. A afirmação ganha relevância ao verificar que, em 1982, haviam mais de 100 rádios livres operando na cidade. Nesta entrevista, Robson César conta como seu amor pelo rádio fez com que ele se enveredasse pelas possibilidades comunicacionais oferecidas por esses veículos de informação. O objetivo desta atividade é complementar os registros acadêmicos sobre a temática. A entrevista foi realizada em Sorocaba, em 24 de abril de 2021, por meio de perguntas semiestruturadas.
\end{abstract}

PALAVRAS-CHAVE: Comunicação radiofônica. Rádios livres. Rádios Livres Sorocabanas. Robson César.

ABSTRACT: Free radios are clandestine vehicles of communication that freely reverberate information through electromagnetic space. In particular, these broadcasters create discourses far from the interests of the telecommunications monopoly. Such initiatives experimented democratic forms of management, by encouraging individuals with no media experience to operate a radio station. In Sorocaba/SP, this popular action gained national and international prominence. This statement gains relevance when verifying that, in 1982, there were more than 100 free radio stations operating in the city. In this interview, Robson César tells about how his love for radio made him embark on the communicational possibilities, offered by these information vehicles. The purpose of this activity is to complement academic records on the subject. The interview was conducted in Sorocaba, on April 24, 2021, using semi structured questions.

KEYWORDS: Radio communication. Free radios. Sorocabanas Free Radios. Robson César.

\footnotetext{
${ }^{1}$ Doutorando pelo Programa de Pós-Graduação em Ciências da Comunicação da Escola de Comunicação e Artes da Universidade de São Paulo (PPGCOM ECA-USP). Bolsista do CNPq. ORCID: 0000-00024160-3065. E-mail: felipe.parra@usp.br.
}

\section{Revista ALTERJOR}

Grupo de Estudos Alterjor: Jornalismo Popular e Alternativo (ECA-USP)

Ano 12 - Volume 01 - Edição 25 - Janeiro-Junho de 2022

Av. Professor Lúcio Martins Rodrigues, 443, Cidade Universitária, São Paulo, CEP: 05508-020 


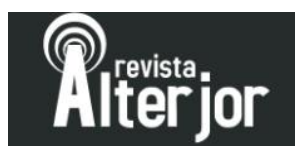

As rádios livres são emissoras clandestinas ${ }^{2}$ que proporcionam a oportunidade de qualquer um se expressar pelo espaço eletromagnético como jamais conseguiriam nas mídias oficiais. Em outras palavras, são meios de comunicação que não exercem qualquer tipo de censura nas mensagens que são veiculadas. Uma iniciativa democrática que transforma a radiodifusão em um mecanismo recepção e produção de informação (SANTORO, 1981). Diante dessa premissa, membros da sociedade era bem-vindos para reverberar seus pensamentos por meio de conteúdos radiofônicos.

Outra particularidade dessas atividades é estimular que pessoas sem especialização operem uma rádio. Nesse sentido, sujeitos são encorajados a se tornarem programadores, DJs e produtores de programas veiculados nessas mídias. Essas nuances fazem com que tais ações sejam uma forma diferente e igualitária de se fazer rádio (MACHADO; MAGRI; MASAGÃO, 1986).

Nas décadas de 1970 e 1980, Sorocaba ficou conhecida como um polo nacional dessas radiodifusoras caseiras devido ao grande número de emissoras que funcionavam no município (SOROCABA, 1984). Essa novidade instigou o público juvenil da cidade a criar suas próprias rádios livres. Entre esses jovens estava Robson César (Fig. 01). O advogado, jornalista, publicitário e radialista viu sua paixão pelo rádio florescer ainda na infância.

Figura 01 - Robson César

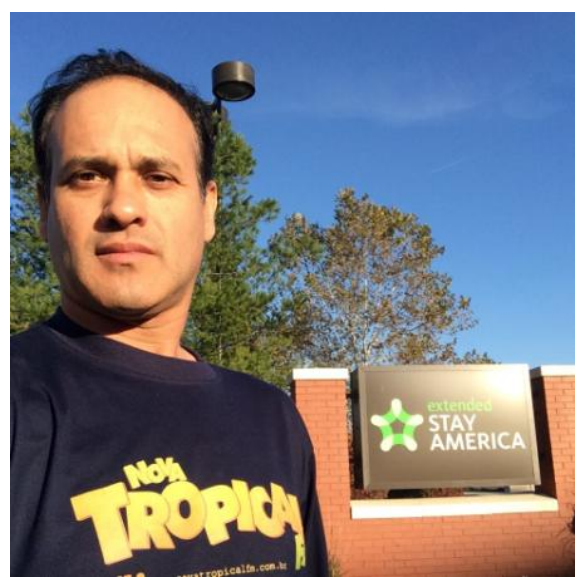

Fonte: arquivo pessoal de Robson César

\footnotetext{
${ }^{2}$ Antes da era digital, as rádios livres ocupavam ilegalmente o espaço eletromagnético controlado pelo monopólio das telecomunicações por meio de transmissores de rádio e outros aparelhos de som caseiros (MACHADO; MAGRI; MASAGÃO, 1986).
}

\section{Revista ALTERJOR}

Grupo de Estudos Alterjor: Jornalismo Popular e Alternativo (ECA-USP)

Ano 12 - Volume 01 - Edição 25 - Janeiro-Junho de 2022 Av. Professor Lúcio Martins Rodrigues, 443, Cidade Universitária, São Paulo, CEP: 05508-020 


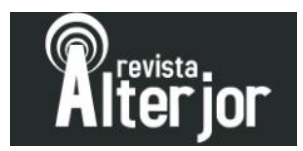

Felipe Parra - Para começarmos, gostaria de saber como surgiu o interesse pelo rádio e o que te motivou a ter uma rádio livre?

Robson César - Tudo começou quando eu ganhei um rádio da minha mãe há muito tempo atrás, um rádio que tinha FM. Até então eu tinha um Evadin pequeno, tenho ele até hoje. Quando minha mãe me deu esse rádio, eu comecei a ouvir as emissoras de Sorocaba e comecei a ter uma afinidade com alguns locutores da Vanguarda FM e fui me apaixonando por rádio. Aí eu ficava na minha casa treinando, tenho essas gravações que eu fazia com 12, 14 anos. Estava ouvindo esses dias e dando risada. Bom, em um belo dia acabei sintonizando em uma rádio que não tinha nada a ver e comecei a me interessar. Todo dia à noite eu ficava ouvindo. O nome dessas rádios eram Spectro, Tropical de Votorantim e Voyage. Essas transmissões eram caseiras, o locutor estava na casa dele falando com outras pessoas pelo rádio. Para fazer isso, ele deixava um rádio sintonizado na emissora da pessoa com quem ele estava falando. Assim, era possível ele falar no microfone e ouvir a resposta pelo rádio. Você, como ouvinte, conseguia ouvir o que vazava do rádio sintonizado no microfone do locutor. Então dava para você ficar acompanhando a conversa inteira. Não era um monólogo. E aí minha mãe me comprou um walkie-talkie lá em Aparecida do Norte. Eu conversava a distância com os meus amigos e, um dia, fui ver se eu conseguia falar com essas rádios pelo walkie-talkie. Ele era muito fraco. Lógico, as rádios livres tinham uma potência melhor. E brincando assim, um dos donos dessas rádios livres me ouviu e falou "quem está aí?" eu fiquei trêmulo. Conversando com ele depois, fiquei sabendo eu era o dono da rádio livre Tropical FM, a 106.1. Aí eu falei para ele que gostaria de ter uma rádio também e ele me fez um transmissor $B F$ (Fig. 02) que eu tenho até hoje. Então, o amor pelo rádio explodiu! Montei uma rádio chamada Edissom com o $B F$, pois ele era mais potente que o walkie-talkie. O nome era Edissom porque tinha uma menina lá da rua chamada Edissa e eu gostava dela, e coloquei Edissom com dois "s".

Revista ALTERJOR

Grupo de Estudos Alterjor: Jornalismo Popular e Alternativo (ECA-USP)

Ano 12 - Volume 01 - Edição 25 - Janeiro-Junho de 2022 Av. Professor Lúcio Martins Rodrigues, 443, Cidade Universitária, São Paulo, CEP: 05508-020 


\section{Pherior}

Figura 02 - Foto do transmissor $B F$ utilizado na rádio Edissom $F M$

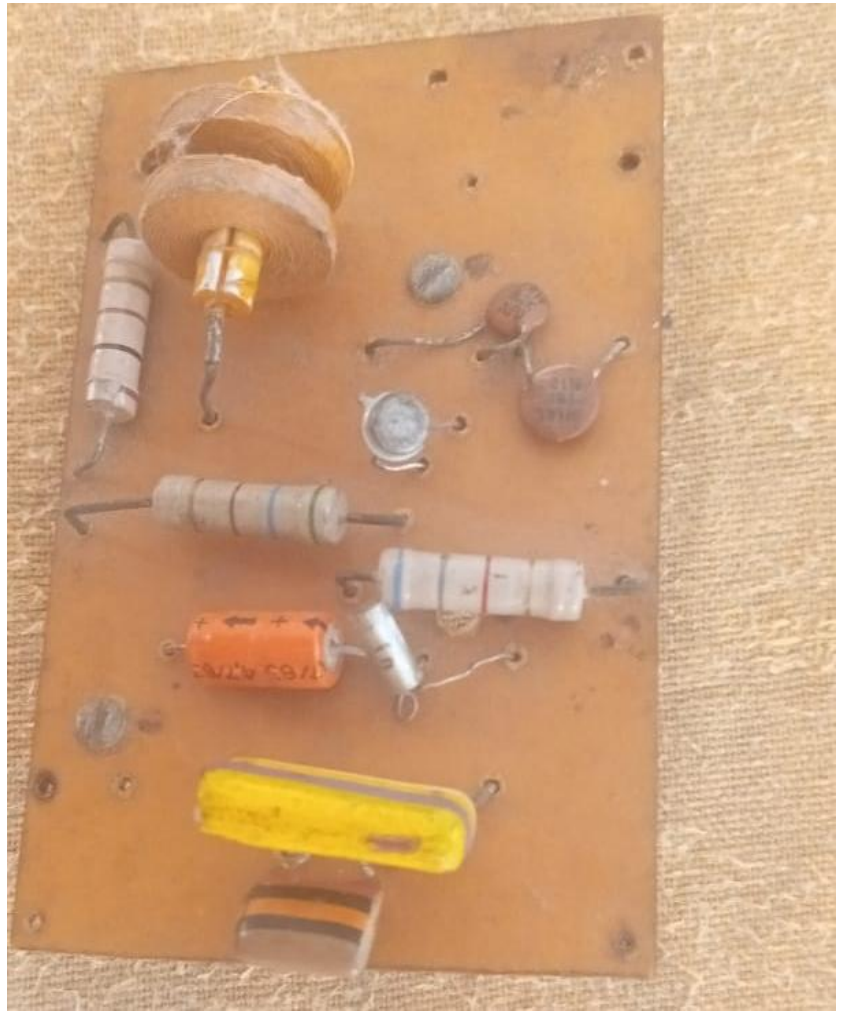

Fonte: arquivo pessoal de Robson César

Meu primo é engenheiro eletrônico. Um dia ele passou na minha casa e falou que meu transmissor era muito fraquinho. Ele me perguntou se eu queria um melhor. Aí ele montou um transmissor chamado 2N2222A. Esse era ótimo. Só que era tudo camuflado. A ideia do meu primo foi pegar uma caixa de conversor UHF normal e montar dentro dessa caixa. Você olhava e pensava que era conversor comum (Fig. 03). Ele deixou só o conector atrás para você colocar a antena, e fez uma antena plano terra para mim. As antenas são na medida da frequência, não sei se você sabe, mas cada frequência tem a medida da sua antena, se for espiral, plano terra, enfim. Quando eu coloquei essa rádio no ar, todo mundo se interessou. Aí eu coloquei no ar a rádio Transuniversal FM. E foi bom porque, através dessa brincadeira, eu consegui passar no teste para o curso de radialista. Em 1985 abriu o curso de radialista no SENAC de Sorocaba e eram cem pessoas inscritas para trinta ou trinta e seis vagas.

\section{Revista ALTERJOR}

Grupo de Estudos Alterjor: Jornalismo Popular e Alternativo (ECA-USP)

Ano 12 - Volume 01 - Edição 25 - Janeiro-Junho de 2022 Av. Professor Lúcio Martins Rodrigues, 443, Cidade Universitária, São Paulo, CEP: 05508-020 


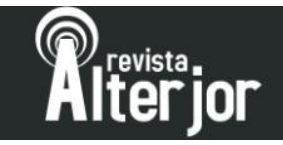

Figura 03 - Foto de um conversor UHF

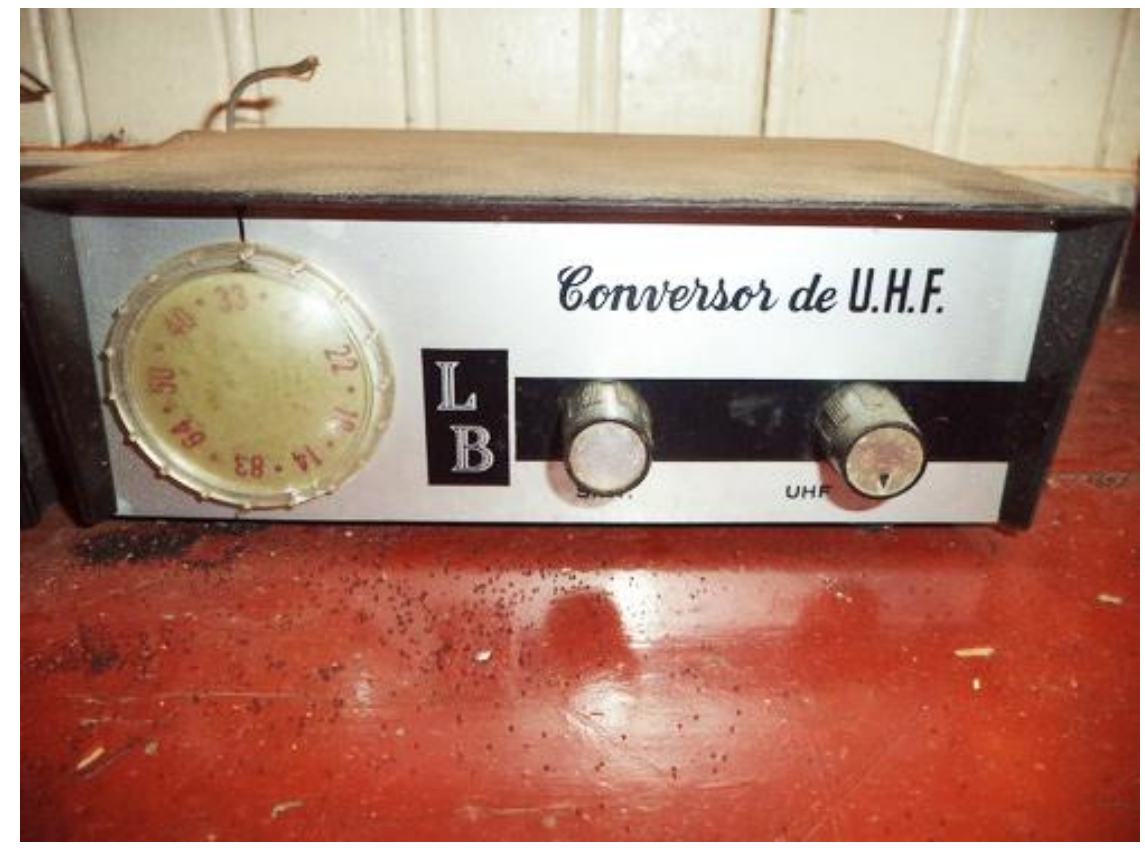

Fonte: arquivo pessoal

Na minha turma esse ano era eu e o Elias Moreno (que depois trabalhou na Ipanema) que não trabalhava em rádio. Enfim, terminei o curso e no mesmo ano comecei a trabalhar na Vanguarda. Quando isso aconteceu, eu dei meu transmissor para o Paulo Stecker. Ele é um grande amigo meu, a gente era parceiro de ouvir música, gravar música, fazer bailinho nas garagens, abraçar a meninas, aquelas coisas que a gente fazia na adolescência. Então, eu passei para ele, falei ' Paulo, cuida aî', Como eu ainda tinha meu $B F$, eu montei uma outra rádio livre por diversão, a Trans II. Só que eu não falava mais nada porque eu era radialista da Vanguarda FM.

F.P. - Pensando em ordem cronológica, que ano você montou essas rádios livres? R.C.- A Transuniversal foi em entre de 1984, 1985. A Edisson foi 84 mais ou menos, pois a Edissa faleceu em acidente de carro, então mudei para Transuniversal. Foi mais ou menos nessa época porque, em 1985, eu comecei a fazer o curso de rádio, me formei e comecei a trabalhar na Vanguarda em dezembro. Em janeiro comecei a fazer locução. Mas mesmo quando eu estava na Vanguarda eu criei outras rádios livres. Eu só ia mudando de nome das rádios. Fiz a Trans II, a Village FM, a Paissandu FM, a Mistério

\section{Revista ALTERJOR}

Grupo de Estudos Alterjor: Jornalismo Popular e Alternativo (ECA-USP)

Ano 12 - Volume 01 - Edição 25 - Janeiro-Junho de 2022

Av. Professor Lúcio Martins Rodrigues, 443, Cidade Universitária, São Paulo, CEP: 05508-020 


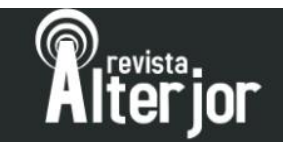

$F M$. Era fácil de mudar a frequência de transmissão pelo transmissor. Eu regulava o aparelho para outra frequência e criava uma nova rádio. Só que eu não podia falar nessas emissoras. Como eu trabalhava em uma emissora comercial, eu conhecia outros radialistas. Eu falava para eles gravarem algumas vinhetas para mim. Aí eu colocava no ar. Gravava essas coisas em um microfone de eletreto. É um microfone bem pequenininho (Fig 04).

Figura 04 - Microfone de eletreto utilizado nas rádios livres de Robson César

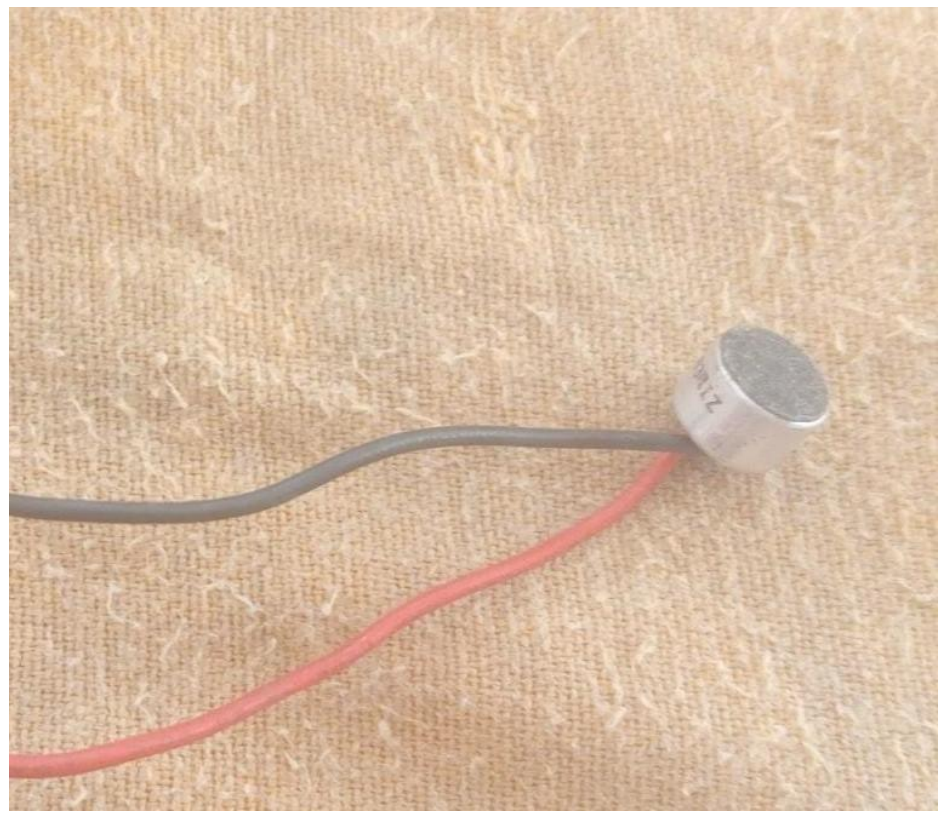

Fonte: arquivo pessoal de Robson César

Em 1996, eu fiz a campanha de um candidato de Votorantim, eu fazia carro e caminhão de som. Ele me pagou pelo trabalho e eu chamei um amigo meu que também era radialista. Sugeri de montarmos uma rádio em Votorantim. Na cidade não tinha rádio. A rádio comunitária Tropical começou em 1998. Montamos e ficamos três meses com ela. Eu estava usando aquele 2N2222A para fazer as transmissões. Aí a Policia Federal chegou lá e fechou a rádio com três meses de funcionamento. Perdemos todos os equipamentos novos. Fomos lá em São Paulo comprar, ali na Santa Efigênia. Tudo foi apreendido. Quase nos prenderam porque, naquela época, era detenção de um a dois anos, mais ou menos isso. Nos ficharam, respondemos processos, tivemos que 


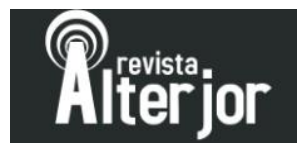

comparecer periodicamente na polícia. No final das contas, fizemos um acordo e pagamos em cesta básica para uma entidade. Como éramos réu primário e não tínhamos antecedentes, conseguimos isso. Mas o dia que eles chegaram lá quase que a gente saiu de camburão.

F.P. - A Polícia Federal lacrou ou levou todos os equipamentos?

R.C. - Levaram tudo, só não levaram a antena porque não conseguiram tirar. A rádio era em um prédio e eles não tinham acesso. Não fui nem eu que coloquei a antena, nós pagamos para um rapaz colocar. Eu nem sei como ele conseguiu. Tanto é que a gente saiu de lá e a antena ficou. Quando deu esse problema, eu estava para casar, casei em 1997. Então, essa situação mexeu com o meu psicológico. Depois não quis nem mais saber, não queria mais me envolver. Eles chegaram lá e lacraram tudo, botaram dentro de um saco e levaram tudo, $\mathrm{CD}$, fita, tudo. Naquela época não tinha disco mais, era CD. Perdi muitos CDs da minha coleção. A polícia chegou ameaçando, você sabe que eles botam o terror. Aí nós ligamos para um amigo nosso que era advogado (ele era procurador na prefeitura) que socorreu a gente. Ele que foi lá e conversou com o advogado da Polícia Federal. Quem autuou a rádio foi um delegado da Polícia Federal. Achavam que a nossa rádio era a mais forte do mundo e não era. Operávamos na frequência 107.9. Não tinha rádio naquela época nessa frequência, então ela expandia muito, chegava longe. A polícia com toda a sistemática de inteligência deles achava que estávamos com um transmissor de $300 \mathrm{MHz}$ e não era. A rádio tinha $25 \mathrm{MHz}$ ou 30 $\mathrm{MHz}$, não lembro. Esse nosso amigo conversou com o delegado da Polícia Federal e sugeriu que eles ficassem com todos os equipamentos e nos liberassem. Isso deu certo, respondemos o processo em liberdade, mas não podendo fazer nada de errado. Até hoje, às vezes vou tirar antecedente criminal e consta lá. Mas já prescreveu.

F.P. - Mas eles chegaram até vocês por denúncia?

R.C. - Denúncia. Nos falaram quem poderia ser, mas estávamos errados. Não tem como, a gente fazia por diversão. Só que essa rádio, a Cidade FM, a gente tinha comercial, tinha vinheta, era uma rádio normal, com qualidade igual às outras, entramos

Revista ALTERJOR

Grupo de Estudos Alterjor: Jornalismo Popular e Alternativo (ECA-USP)

Ano 12 - Volume 01 - Edição 25 - Janeiro-Junho de 2022

Av. Professor Lúcio Martins Rodrigues, 443, Cidade Universitária, São Paulo, CEP: 05508-020 


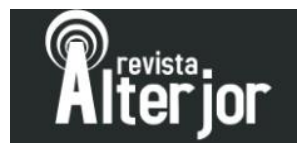

para competir mesmo com as rádios oficiais. O que mais incentivou a montarmos essa emissora sem concessão foi o discurso de um deputado de São Paulo. Eu o conheci em 1995 e ele defendia muito as rádios comunitárias. Na época não existia esse tipo de rádio no Brasil. Eram só rádios piratas, rádio livres. Eu participei várias vezes de reuniões com ele em São Paulo e ele falava "Pode montar, se a polícia chegar, você liga para minha assessoria', Mas não aconteceu nada disso. Então quando eu montei a rádio da maneira que nós montamos, ele disse para fazermos e depois entrar com processo de legalização de emissora. No fim deu nisso. Mas esse é um fato interessante porque ele era um grande incentivador das rádios comunitárias. Foi o trabalho e a persistência dos donos das rádios livres que deu muita força para os deputados criarem a lei das rádios comunitárias. Isso foi muito pela resistência dessa turminha das rádios livres. Eu sou testemunha. Meia hora depois da polícia fechar uma rádio livre, ela já voltava a funcionar com outro transmissor. Era na teimosia.

F.P. - Vocês tinham alguma visão politica dentro da rádio?

R.C. - Nenhuma. A ideia nas minhas rádios era montar um padrão mais comercial. Mesmo eu vindo de uma campanha política, meu candidato perdeu. Eu poderia até bajular esse político, mas não, eu não tinha nenhuma relação partidária e nada, estava super tranquilo.

F.P. - Qual era a programação das suas rádios livres?

R.C. - Quando eu comecei lá com meu walkie-talkie e depois com meu BF, era mais para conversar com o pessoal. Depois que eu peguei o 2N2222A. Esse é mais forte e começou a pegar longe, aí eu fazia uma programação de rádio comercial, tocava as músicas que eu gostava. Eu não fazia rádio para Sorocaba. Não fazia rádio para Araçoiaba. Fazia rádio para o meu reduto ali no bairro. Para as meninas que gostavam de Guilherme Arantes, Michael Jackson e era isso, eu mandava músicas para elas. Para os amigos também, do comércio. Enfim, era praticamente música comercial, não era tão eclético como algumas que tocavam na época de Beethoven a David Lee Roth. Na minha rádio eu comprava LP e tocava. Também tinha as fitas cassetes. Gravava músicas

\section{Revista ALTERJOR}

Grupo de Estudos Alterjor: Jornalismo Popular e Alternativo (ECA-USP)

Ano 12 - Volume 01 - Edição 25 - Janeiro-Junho de 2022

Av. Professor Lúcio Martins Rodrigues, 443, Cidade Universitária, São Paulo, CEP: 05508-020 


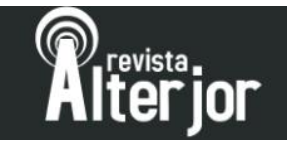

de outras rádios e ia ao ar. Comprei um mix na época. Cheguei a fazer remixagem, acoplava o microfone. Basicamente isso, bem rudimentar mesmo. Até tem uma passagem interessante. Você entrevistou Antonio Isaias Antunes Pereira ${ }^{3}$, da rádio Columbia FM. Ele me assustou quando foi na minha casa! Eu morava no bairro do Rio Acima, em Votorantim. Ele chegou na minha casa com roupa social e uma pasta debaixo do braço. Ele bateu palma e eu sai lá falando "pois não" e ele disse que era da Polícia Federal. Quase desmaiei! Eu tinha 12, 14 anos na época. Faz praticamente quarenta anos que eu não vejo o sr. Antonio.

F.P. - E durante essa programação, você fez algum tipo de publicidade para algum estabelecimento? Fez algum comercial?

R.C. - Sim, de graça. Fiz para diversos comércios. L Som, Flávia Cosméticos, Vototal Esportes etc. A L Som existe até hoje, eu tenho esses comerciais gravados inclusive, estava ouvindo essas fitas. A Flávia Cosméticos eu nem sabia quem era, nem conhecia, mas para dar aquele ar de rádio comercial, profissional, eu fazia. Eu tinha um amigo e ele ia à minha casa e gravava os comerciais para não ficar minha locução. Para variar a locução, eu pedia para uma amiga minha gravar as vinhetas, ela tinha uma voz anasalada. Praticamente esse tipo de programação. Era uma coisa bem feita, tentava imitar bem uma rádio comercial, no final de música eu abria o microfone (Fig. 05) e falava, mandava recado, passava a hora. Para o bairro mesmo, eu não me preocupava se a rádio chegava em Sorocaba. A própria turma que me conhecia no bairro ligava para minha casa e pediam a música. Eu me sentia importante porque, até então, eu não era locutor de rádio profissional, comecei no final de 1985 para 1986. Essa foi uma grande escola para mim, é o que eu te falei, eu consegui passar no curso do SENAC porque eu já brincava com isso, era um laboratório. Se fosse falar o que eles deram para ler na hora, fazer entonação de voz, eu não ia conseguir.

\footnotetext{
3 A entrevista com Antonio Isaias Antunes Pereira foi publicada na revista científica Tríade: Comunicação, Cultura e Mídia (PEREIRA, 2020).
}

Revista ALTERJOR

Grupo de Estudos Alterjor: Jornalismo Popular e Alternativo (ECA-USP)

Ano 12 - Volume 01 - Edição 25 - Janeiro-Junho de 2022

Av. Professor Lúcio Martins Rodrigues, 443, Cidade Universitária, São Paulo, CEP: 05508-020 


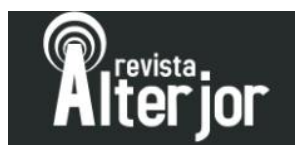

Figura 05 - Microfone utilizado nas rádios livres de Robson César

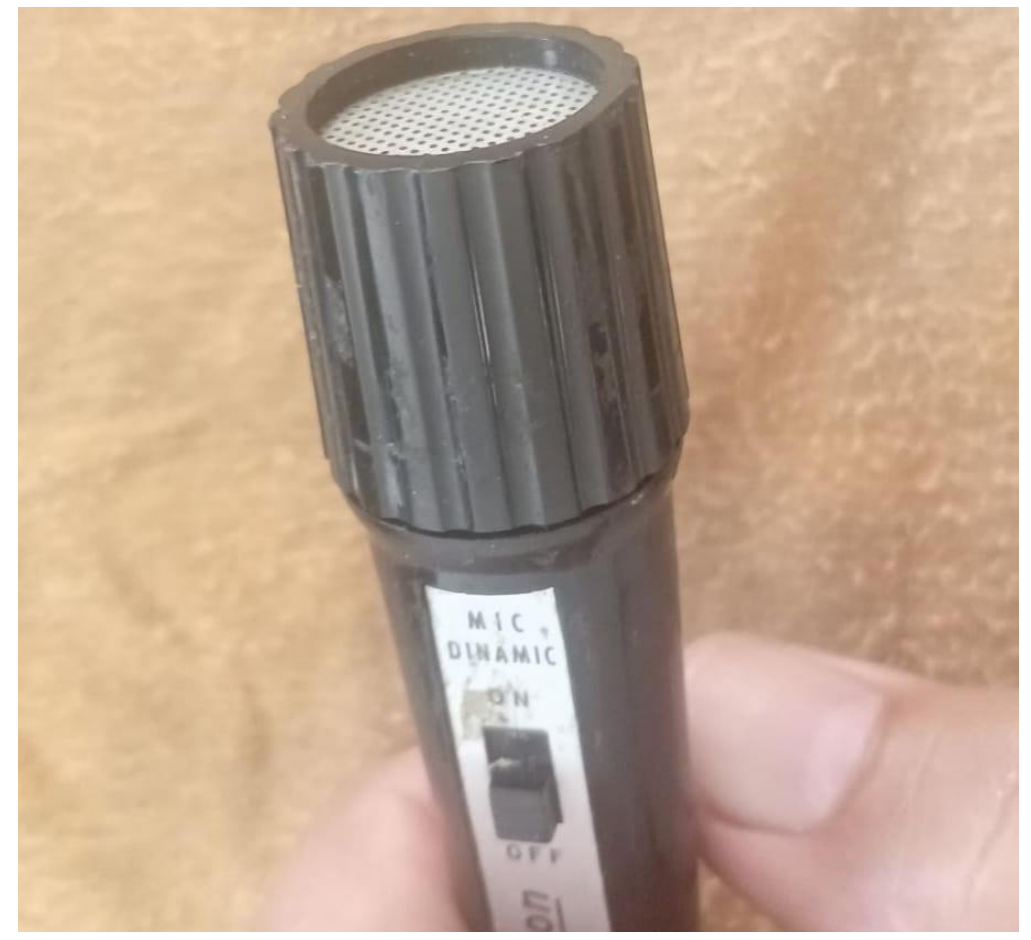

Fonte: arquivo pessoal de Robson César

F.P. - E quanto a entrevistas, você fez alguma?

R.C.- Sim, eu fiz. Eu era meio louco, audacioso. Cheguei a entrevistar o Antônio Ermírio de Moraes, quando ele foi candidato a governador. Ele veio em Votorantim. O helicóptero desceu no Clube Atlético Votorantim e eu estava lá com um gravador National. Gravei uma entrevista com ele no meio de todo mundo (Fig. 06). Eu chamava também os amigos que iam à minha casa conversar, tenho gravações do Paulo Stecker brincando, batendo um papo. Outra coisa legal é que eu era meio Professor Pardal ${ }^{4}$. A televisão da minha casa tinha uma saída de som que eu acho que era para fone de ouvido. Eu conectava o tape do som na saída da TV. Então, de vez em quando, eu gravava programas jornalísticos e depois colocava como se fosse jornalismo da rádio. Tenho também isso gravado nas fitas.

\footnotetext{
${ }^{4}$ Professor Pardal (Gyro Gearloose nos Estados Unidos) é um personagem de ficção, um garnisé antropomorfo criado em 1952 por Carl Barks para a Walt Disney Company.
}

\section{Revista ALTERJOR}

Grupo de Estudos Alterjor: Jornalismo Popular e Alternativo (ECA-USP)

Ano 12 - Volume 01 - Edição 25 - Janeiro-Junho de 2022 


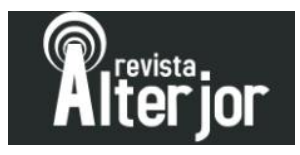

Figura 06 - Robson César entrevistando Antônio Ermírio de Moraes em 11/10/1986

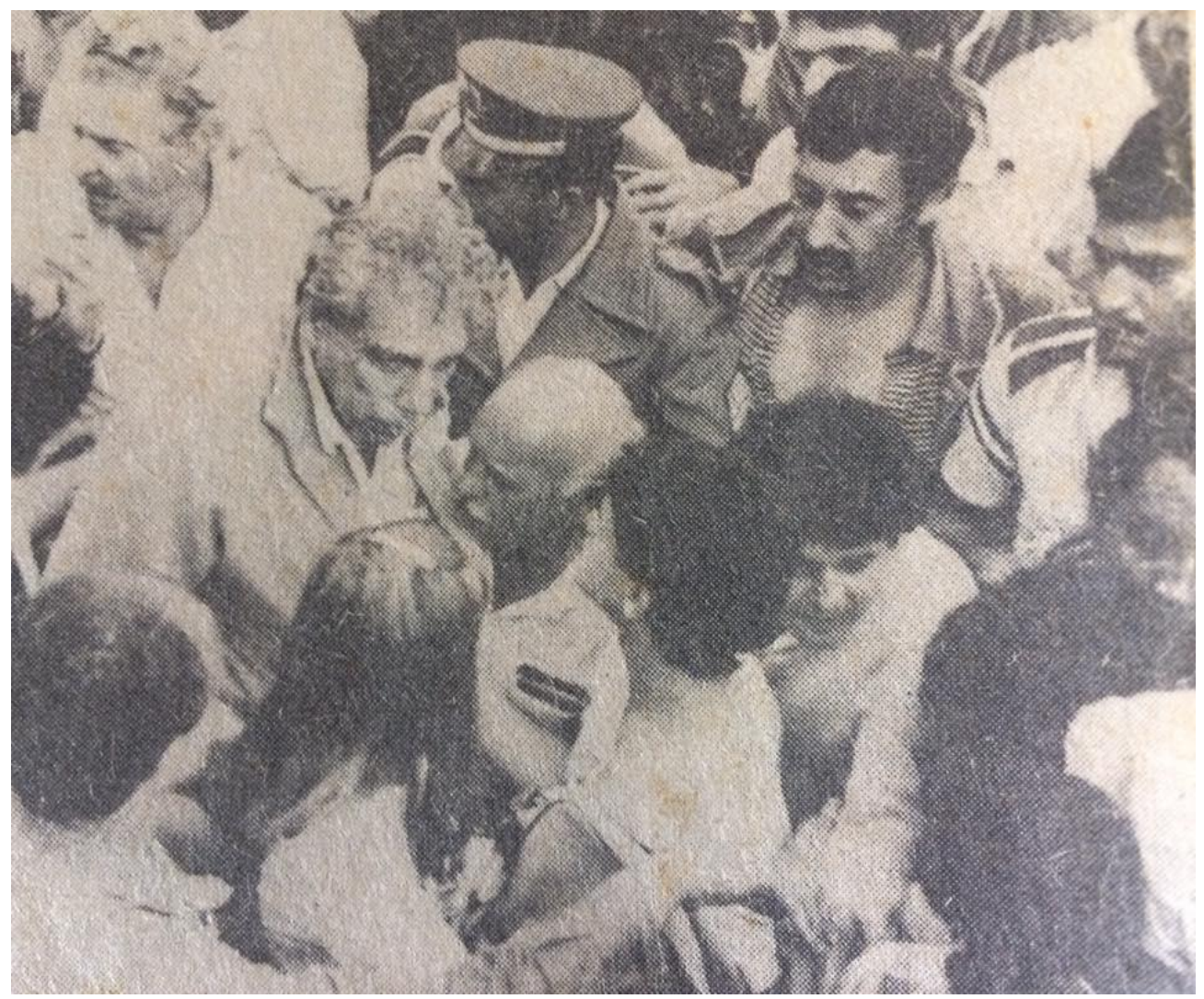

Fonte: arquivo pessoal de Robson César

F.P. - Nessa época você já conhecia as rádios livres, ou rádios piratas de outros lugares do mundo?

R.C. - Não, e eu nem sabia que existia. O que eu conhecia eram as rádios Spectro, Voyage, Columbia, Tropicana, Tropical, essa turminha daqui e só. Eu nem sabia da existência de outras rádios. Eu achava muito bacana ligar a noite e ouvir os caras conversando, batendo papo e eu quis entrar nessa onda. Mas eu não tinha conhecimento do movimento mundial das rádios livres, eu não tinha essa dimensão, para mim era local mesmo.

F.P. - Você tinha alguma periodicidade em suas rádios livres? Que horas você entrava no ar?

R.C. - Até os 18 anos eu não trabalhei, então eu tinha todo o tempo do mundo. Eu joguei futebol, estudava a noite, fazia tudo que eu queria. Nessa época eu ligava a rádio

Revista ALTERJOR

Grupo de Estudos Alterjor: Jornalismo Popular e Alternativo (ECA-USP)

Ano 12 - Volume 01 - Edição 25 - Janeiro-Junho de 2022

Av. Professor Lúcio Martins Rodrigues, 443, Cidade Universitária, São Paulo, CEP: 05508-020 


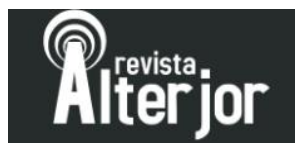

de dia, ligava no fim de semana à noite, na tarde de sábado. Não tinha essa periodicidade certinha, de segunda a sábado, das nove as dez. Na rádio Cidade tinha até equipe lá. Como era uma proposta mais profissional, nós tínhamos os horários, mas a rádio livre era sem compromisso, ligava quando tinha tempo, era mais pro bairro.

F.P. - Qual era a sua motivação em ter uma rádio livre? Era para entretenimento ou tinha algo mais?

R.C. - Como eu falei para você, eu me interessei pelo rádio desde quando eu ganhei um radinho da minha mãe. Nesse tempo eu só conhecia rádios AM. A partir do momento que chegou o FM, deu para sentir a diferença. Era outra coisa, mais jovem, diferente e eu me apaixonei por isso. Como eu tinha um microfone e um gravadorzinho, eu ficava brincando em casa. Depois montei os sistemas bem caseiros de rádio com o $B F$. E eu fazia tudo isso em um gradiente DS40, que eu tenho até hoje funcionando.

F.P. - Você conversava com o pessoal pela rádio, mas vocês tinham encontros presenciais, se viam ao vivo?

R.C. - Não.

F.P. - Era por medo da polícia?

R.C. - Olha, eu creio que por parte deles sim. Para você ter uma ideia, eu conheci o dono a extinta Studio FM recentemente. Eu conhecia somente por áudio. Nunca tinha visto a pessoa. Somente depois que nós conversamos sobre rádio que nos demos conta que nos conhecíamos a muito tempo já. Hoje ele está nos EUA, a mulher dele foi estudar e ele foi junto e acabou ficando. Isso já faz uns quatro anos.

F.P. - E em relação as mídias tradicionais daqui de Sorocaba na época, qual era a posição do Jornal Cruzeiro do Sul e das rádios comerciais em relação as rádios livres? Qual era a impressão que a sociedade tinha das rádios livres?

R.C. - Veja bem, Felipe, eu vou passar para você algumas gravações que eu tenho da época e você vai ouvir. O problema era que falávamos muita besteira, coisa pesada 


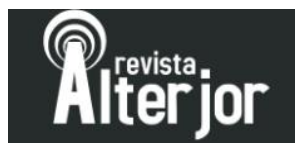

mesmo. Então imagina, naquela época não era tão liberal como é hoje, depois que entrou Faustão na Globo melhorou. Mas, em 1987/1988, o sistema era mais rígido. Eu falo por mim, pelo meu pensamento e pela minha visão, eu creio que realmente tinha certa resistência da sociedade por esse tipo de comportamento e de linguagem que era usado em algumas rádios daqui. Eu nunca fui para esse lado. O Paulo Stecker e eu entravamos no microfone só para anunciar o que viria em seguida, mas os outros locutores não, eles falavam muita besteira.

F.P. - Você queria tem uma programação semelhante à das rádios comerciais para ter uma chance de entrar e trabalhar em uma rádio oficial?

R.C. - Não, foi um acontecimento. Eu até comentei com uma amiga esses dias sobre isso. Teve uma pessoa marcou muito na minha vida. Esse sujeito me criticou severamente e foi meu grande incentivador. Eu fazia teatro em 1984, no Fórum Velho em Sorocaba. Nessa época eu já tinha a rádio e brincava com ela. Então, nos intervalos do teatro, eu ficava fazendo locução. Um dia esse professor me ouviu e falou para mim “Com essa voz de taquara rachada você nunca vai ser locutor". Falou no meio de todo mundo. E aquilo marcou muito para mim. Mas, graças a Deus, foi através do rádio que eu trabalhei em televisão e construí minha carreira. As coisas foram acontecendo. Corri atrás e fiz o curso. Lembro que eu não tinha diploma e fui à rádio Vanguarda uma vez. Eu admirava muito um locutor dessa emissora. Perguntei para um funcionário da rádio, o sr. Camargo, como eu fazia para fazer teste na Vanguarda. Ele me perguntou se eu tinha diploma de radialista. Obviamente eu não tinha. Aí ele falou que no dia que eu tivesse diploma podia voltar lá e procurar ele. Fiquei com isso gravado na minha cabeça. Fiz o curso e peguei o diploma. No dia seguinte eu estava na Vanguarda. Isso foi no final de 1985, em dezembro. Com o diploma na mão, me deram uma chance. $\mathrm{Na}$ verdade, não era só o sr. Camargo, teve uma equipe que me ajudou muito. Mas o Eduardo foi a pessoa que me recebeu de braços abertos dentro da Vanguarda. Eu ligava muito para os locutores, pedia música, ficava conversando com eles no período da noite (era um período mais tranquilo) e fui fazendo amizade. Me convidavam muitas vezes para ir na Noite da Rádio Cacique e eu ia! Não tinha carro, não tinha nada, eu pegava o 


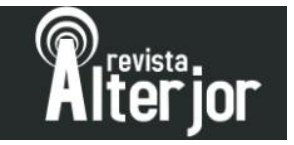

ônibus e ia com a turma. Ia em shows e não sabia como ia voltar, ficava procurando amigo para pedir uma carona, fiz muito disso. Minha estreia na rádio Vanguarda foi dia 25 de janeiro de 1986. Liguei o microfone para falar "Vanguarda FM, 15h20" ou "Vanguarda FM, 18h30". Era isso, o nome da rádio e a hora. Essa passagem foi interessante, mas tudo foi acontecendo, eu fui buscando. Uma coisa interessante na minha carreira foi a visão de negócio que o sr. Salomão Pavlovsky me deu. Até hoje, o salário de locutor de rádio é pouco. Um dia eu estava lá e fui gravar e o sr. Salomão Pavlovsky me falou "O senhor quer ganhar dinheiro com rádio? Venha na minha sala conversar comigo", e aí eu fui lá e ele explicou que para ganhar dinheiro com rádio tem que vender comercial. Na época a TV estava implantando seu modelo de negócio, era mais o rádio AM e FM. Ele fez uma pastinha para eu vender publicidade e eu saí vendendo. Lembro que, no segundo mês, eu já tirei um valor próximo do meu salário só em publicidade. Aí eu vi que era isso que realmente dava dinheiro. Comecei também a trabalhar com venda de publicidade. Devido essa dica do sr. Salomão Pavlovsky, eu tive um jornal na cidade, não em Sorocaba, foi na minha cidade. Trabalhei também em outras rádios, trabalhei em outras TVs, não só como apresentador, mas também vendendo publicidade. Isso dava um considerável ganho extra no final do mês.

F.P. - Hoje você não trabalha mais com rádio?

R.C. - Em 1999 eu fui para o litoral. Casei em 1997 e em 1999 fui trabalhar em uma empresa de saúde em Santos onde fazia parte de comunicação e marketing. Eu estava terminando o curso de Jornalismo, mas surgiu essa oportunidade e eu fui para lá. Em Santos eu fiz a TV Mar e fiz uma rádio em São Vicente que eu não lembro o nome. Ficava muito contramão e eu não consegui conciliar a rádio com a TV Mar. Esse canal de TV que fazia aquele shopping publicidade e a rádio fazia programa de música, era mais final de semana, no sábado. Em 2000, o candidato que eu fiz a campanha que perdeu em 1996, ele ganhou. Eu participei da campanha dele. Nessa mesma época, eu me formei em Jornalismo e ele me convidou para trabalhar na prefeitura em 2001, quando ele assumiu o cargo. Me mudei de volta para Votorantim e vim trabalhar na prefeitura onde eu estou até hoje. Já estou há 20 anos trabalhando na Prefeitura de 


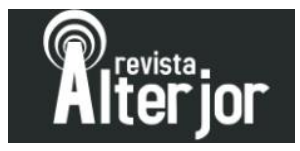

Votorantim. Durante esse período, eu também fiz TV e fui diretor de uma rádio comunitária, a Tropica FM. Nós conseguimos junto com o Pannunzio, que na época era Deputado Federal, entrar com o processo da legalização da Tropical FM. Graças a Deus, em 1998, veio a concessão e a rádio começou a trabalhar legalizada mesmo. Depois de algumas trocas de liderança, eu presidi a rádio. Foi muito legal e aproveitei para colocar em prática tudo que sabia de rádio (sobre equipamento, plástica e tudo mais). Após minha saída da Tropical eu não mexi mais com rádio, pois meu filho nasceu em 2011. Comecei a me dedicar mais a família. Conciliar o trabalho no poder público, o trabalho na rádio e a família fica pesado. Até tive vontade de voltar em 2019. Mas não deu certo porque era um horário complicado. Mas eu sinto falta sim.

F.P. - Agora em relação as suas rádios livres, você mesmo consertava e regulava seus aparelhos? Como era isso?

R.C. - Não, eu sou zero em eletrônica. Nos meus equipamentos aqui eu até borrifo um pouco de limpa contato, troco uma correia, coisa simples. Mas a parte de eletrônica, com capacitor, eu não sei muito. Como eu falei, o meu primo é engenheiro eletrônico. Qualquer coisa eu ligava para ele, mas nunca tive problemas, nunca. Aquele transmissor que ele fez dentro do conversor UHF durou até o dia que a polícia levou embora.

F.P. - Sobre a programação da rádio, como você fazia? Você editava esses conteúdos sonoros?

R.C. - Na unha. Hoje é tudo mais fácil, naquela época não tinha esses recursos. Era na lâmina do estilete. Você pegava a gravação e colocava no equipamento, ouvia a vinheta, marcava e cortava com a lâmina e emendava com Durex. Eu sei que tem uma fita própria, mas eu usava Durex mesmo. Ia cortando em pedacinhos e fazia as vinhetas, principalmente da Village FM. Eu montava na mão, não tinha recurso. Eu tenho umas gravações da época que eu fazia remixagem e eu voltava o disco com o dedo e soltava no pause.

Revista ALTERJOR

Grupo de Estudos Alterjor: Jornalismo Popular e Alternativo (ECA-USP)

Ano 12 - Volume 01 - Edição 25 - Janeiro-Junho de 2022

Av. Professor Lúcio Martins Rodrigues, 443, Cidade Universitária, São Paulo, CEP: 05508-020 


\section{Ritieior}

F.P. - Pelo que você relatou, você tem um considerável número de gravações originais das rádios livres sorocabanas.

R.C. - Sim, tenho separado o que é música, o que eu gravei, as fitas originais que comprava, o que gravei de outras rádios. Comecei a procurar áudios das rádios livres. Pelo que vi, tenho umas trinta fitas. Não consegui ouvir todas. Porém, as principais eu separei e estão comigo. Estou digitalizando esse material. Minha esposa me pergunta o motivo de eu guardar essas coisas. São boas recordações. Eu falei também com o dono da extinta rádio livre chamada Frankstape. Perguntei para ele se tinha algum material gravado. Ele trabalha comigo. Eu tenho um chaveirinho branco e vermelho, escrito Frankstape FM. Vou achar isso, é muita coisa. A rádio Frankstape era mais antiga que as minhas, ouvia no meu walkie-talkie. Eu morava de um lado da avenida e ele morava do outro, atrás de uma escola. Entrei em contato pelo walkie-talkie e ele me perguntou de onde eu estava falando. Pela troca de coordenadas a gente se encontrou. Foi um pouco antes de eu começar a Edissom FM com o BF.

F.P. - Há mais alguma coisa que você queira falar sobre as rádios?

R.C. - É uma coisa que está no sangue e continua até hoje. Tanto é que continua, por isso que eu estou falando para você. Ultimamente estou bem atarefado, mas separei um tempo só para te atender porque eu achei muito legal isso que você está fazendo! Quero te dar os parabéns mesmo por esse estudo. Isso vai ficar eternizado na história.

\section{Referências}

MACHADO, Arlindo; MAGRI, Caio; MASAGÃO, Marcelo. Rádios livres: reforma agrária no ar. São Paulo: Brasiliense, 1986.

PEREIRA, Antonio Isaias Antunes. Estação de frequência modulada da rede alternativa de radiodifusão: AntonioIsaias Antunes Pereira fala sobre as rádios livres sorocabanas Columbia e Rádio Atividade. [Entrevista concedida a] Felipe Parra e Luciano Victor Barros Maluly. Revista Tríade: Comunicação, Cultura e Mídia. Sorocaba, v. 8, n. 17, p. 189-204, 2020. Disponível em:

Revista ALTERJOR

Grupo de Estudos Alterjor: Jornalismo Popular e Alternativo (ECA-USP)

Ano 12 - Volume 01 - Edição 25 - Janeiro-Junho de 2022

Av. Professor Lúcio Martins Rodrigues, 443, Cidade Universitária, São Paulo, CEP: 05508-020 


\section{Areiorior}

<http://periodicos.uniso.br/ojs/index.php/triade/article/view/3848/3723>. Acesso em: 10 nov. 2020.

SANTORO, Luiz Fernando. Rádios livres: o uso popular da tecnologia. Revista Comunicação e Sociedade, São Bernardo do Campo, v. 3, n. 6, p. 97-103, 1981.

SOROCABA, a capital das rádios piratas. O Cruzeiro do Sul, Sorocaba, 11 março. 1984. Sorocaba, p. 16. 